\title{
Platelet indices in the differential diagnosis of thrombocytosis
}

\author{
Bashar A. Saeed*, Sana M. Taib*, Khalid Nafih** \\ *Department of Pharmacology, **Department of Medicine, College of Medicine, University of Mosul.
}

(Ann. Coll. Med. Mosul 2009; 35(1): 33-36).

Received: $2^{\text {nd }}$ Mar 2008; Accepted: $22^{\text {nd }}$ Feb 2009.

\begin{abstract}
Objective: To assess the role of platelet indices mainly: Mean Platelet Volume (MPV) and Platelet Distribution Width (PDW) for the differential diagnosis of thrombocytosis.

Methods: A prospective case series study conducted at Ibn-Sena Teaching Hospital in Mosul during the period from June 2003 to January 2005. Ninety two patients with thrombocytosis were analyzed for platelets indices using Coulter MS-9. A control group of sixty normal subjects were also included in this study for comparison.
\end{abstract}

Results: Thrombocytosis was found to be due to two main causes: 12 patients with myeloproliferative disorders, and 80 patients had secondary reactive causes of thrombocytosis. Patients with myeloproliferative disorders had significantly higher Mean Platelet Volume (MPV) than those with reactive thrombocytosis. Also the Platelet Distribution Width (PDW) was higher in patients with myeloproliferative disorders than those with reactive thrombocytosis and control group.

Conclusion: Platelet indices especially PDW seem to be a good variable for the differential diagnosis of thrombocytosis.

Keywords: Thrombocytosis; platelet indices Mean Platelet Volume (MPV); Platelet Distribution Width (PDW).

الخلاصة

أهداف البحث: أجريت هذه الدراسة لمعرفة أهمية البيانات المتعلقة بالأقراص الدموية في الأجهزة المتوفرة في في

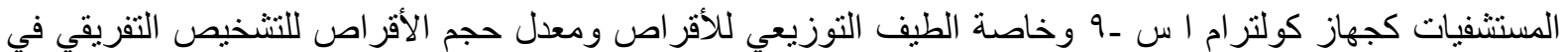

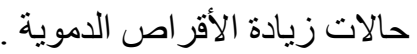

طريقة البحث: دراسة مستقبلية لمجموعة من الحالات. تمت الدراسة في مستشفى ابن سينا التعليمي في الموصل من

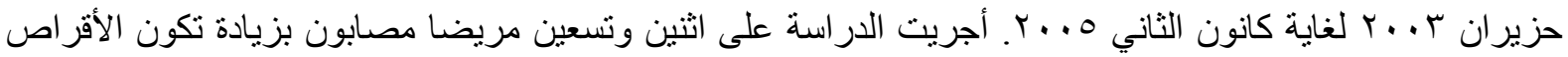

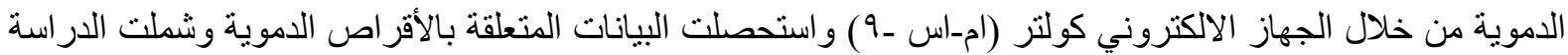

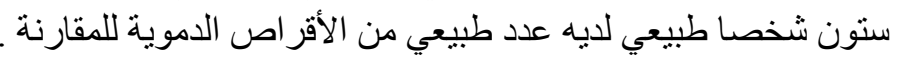

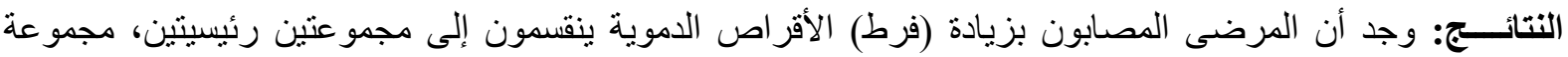

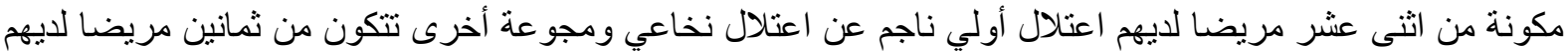

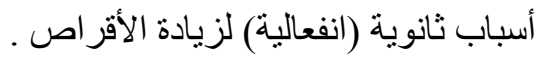
إن المرضى الذين لديهم اعتلال أولي نخاعي كسبب لزيادة الأقراص الداموية فان الطيف التوزيعي للأقراص الدموية

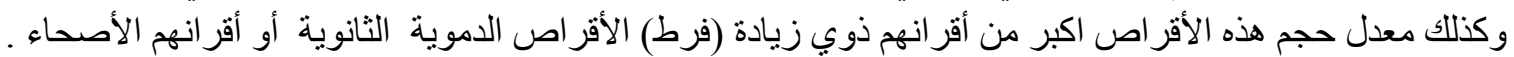

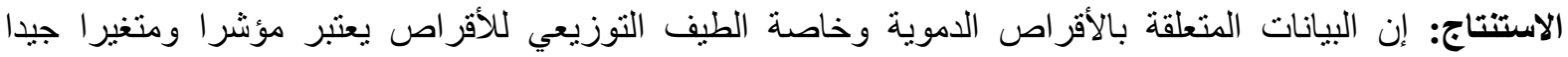
للتشخيص التقريقي في حالات فرط الأقر اص الدموية بنو عيه. 
المفتاح: فرط (زيادة) الأقراص الدموية ، بيانات الأقراص الدموية ، معدل حجم الأقراص الدموية ، الطيف التوزيعي

$\mathrm{T}$ hrombocytosis is the presence of abnormally high number of platelets in the circulating blood. It may result from various physiological stimuli and pathological processes. ${ }^{(1)}$ Thrombocytosis can result from a myeloproliferative disorder, but is more commonly found as reactive phenomenon not caused by a bone marrow diseases but secondary to various pathological states. (2)

Platelet size follows a log-normal distribution and platelet volume heterogeneity has been the subject of considerable investigation, speculation and indeed controversy in recent years. ${ }^{(3)}$

Platelets from patients with myeloproliferative thrombocytosis may differ from those with reactive thrombocytosis in morphology platelet volume distribution pattern. ${ }^{(4)}$

The study aims to assess the efficiency of Coulter MS -9 and of the derived variables; Mean Platelet Volume (MPV) and Platelet Distribution Width (PDW) for the differential diagnosis of thrombocytosis.

\section{Methods}

Ninety two patients with thrombocytosis, i.e. platelets count $>400 \times 10^{9} / \mathrm{L}$, were included in this study, twelve patients with myeloproliferative disorders were studied; the rest were 80 patients with reactive thrombocytosis. A control group of 60 people with mean platelets count of $255 \times 10^{9} / \mathrm{L}$ with a range (162$388 \times 10^{9} / \mathrm{L}$ ) were included for comparison.

The platelet volume analysis was made using a Coulter counter MS-9; particles with a volume between 2 and $20 \mathrm{FL}$ are classified by this instrument as platelets by definition, a volume distribution histogram is generated and fitted to the nearest log. Normal curve therefrom, the platelet count, MPV and PDW are computed..$^{(5)}$

PDW is calculated from the volume of $16^{\text {th }}$ and $84^{\text {th }}$ percentile ${ }^{(6)}$; all measurements were made between one and six hours after the blood had been collected. ${ }^{(7)}$
Statistical analysis was done using unpaired $t$ test , mean and S.D.

\section{Results}

Patients with thrombocytosis were classified according to the cause into primary (myeloproliferative) thrombocytosis (12) patients and secondary (reactive) thrombocytosis (80 patients).

Details of the aetiological classification were summarized in (Table 1)

Table (1): Classification of patients with primary and secondary thrombocytosis

\begin{tabular}{|l|c|}
\hline \multicolumn{1}{|c|}{ Diagnosis } & $\begin{array}{c}\text { Total no of } \\
\text { cases }\end{array}$ \\
\hline \hline $\begin{array}{l}\text { 1. Primary: No. (12) } \\
\text { polycythaemia vera } \\
\text { chronic myeloid leukaemia }\end{array}$ & 3 \\
\hline $\begin{array}{l}\text { 2. secondary (reactive) } \\
\text { No. (80) }\end{array}$ & 9 \\
\hline Infection & 25 \\
\hline $\begin{array}{l}\text { Non haematological } \\
\text { malignancies }\end{array}$ & 23 \\
\hline \begin{tabular}{l} 
Iron deficiency anaemia \\
\hline Haemolytic anaemia
\end{tabular} & 6 \\
\hline $\begin{array}{l}\text { Post operative including post } \\
\text { splenectomy }\end{array}$ & 5 \\
\hline Collagen disease & 1 \\
\hline
\end{tabular}

Table (2): Mean values of different platelet variables in normal and patient groups

\begin{tabular}{|l|c|c|c|c|}
\hline & $\begin{array}{c}\text { No of } \\
\text { cases }\end{array}$ & $\begin{array}{c}\text { Mean } \\
\text { platelet } \\
\text { count } \\
\left(10^{9} / \mathrm{l}\right)\end{array}$ & $\begin{array}{c}\text { MPV } \\
\text { (fl) }\end{array}$ & PDW \\
\hline $\begin{array}{l}\text { Normal } \\
\text { subjects } \\
\text { (control) }\end{array}$ & 60 & 255 & 7.2 & 7.7 \\
\hline $\begin{array}{l}\text { Reactive } \\
\text { Thrombocytosis }\end{array}$ & 80 & 537 & 6.7 & 7.4 \\
\hline $\begin{array}{l}\text { Primary } \\
\text { Thrombocytosis }\end{array}$ & 12 & 625 & 7.45 & 8.7 \\
\hline
\end{tabular}


The mean platelets count in the control group was $255 \times 10^{9} / \mathrm{L}$ with a range $\left(162-388 \times 10^{9} / \mathrm{L}\right)$ in comparison with $537 \times 10^{9} / \mathrm{L}$ in reactive thrombocytosis, with a range $\left(420-580 \times 10^{9} / \mathrm{L}\right)$, while the mean platelet count was $625 \times 10^{9} / \mathrm{L}$ in primary thrombocytosis with wide range $\left(490-1380 \times 10^{9} / \mathrm{L}\right)$.

The Mean Platelet Volume (7.45) in primary thrombocytosis was significantly higher than in reactive thrombocytosis $(6.7)(p<0.01)$.

Also the Platelets Distribution Width (PDW) in primary thrombocytosis (8.7) was significantly higher than in reactive thrombocytosis (7.45) ( $p$ value $<0.01$ ). (Table 2 )

\section{Discussion}

In patients with primary thrombocytosis there is increased platelet heterogeneity while in secondary (reactive) thrombocytosis this platelets' heterogeneity is only sporadically seen. ${ }^{(8)}$ In patients with primary thrombocytosis there are often abnormalities in platelets' morphology in blood smears including increased percentage of megathrombocytes and giant platelets. By coulter MS- 9 counter platelet volume analysis, the percentage of micro-platelets however was also increased; this leads to increase in platelet heterogeneity. $(9,10,11)$ This is also true in our study in which PDW in primary thrombocytosis (8.7) was significantly higher than in reactive thrombocytosis (7.4) because of platelet heterogeneity.

The mean platelet count in the control group was $255 \times 10^{9} / \mathrm{L}$ in comparison with $537 \times 10^{9} / \mathrm{L}$ in reactive thrombocytosis. The mean platelet count in primary thrombocytosis was $625 \times 10^{9} / \mathrm{L}$.

The mean platelet volume (MPV) in patients with primary thrombocytosis was $7.45 \mathrm{fl}$ which was significantly higher than in reactive thrombocytosis $6.7 \mathrm{fl}(p<0.01)$ but was not significantly different from control group in which MPV was $7.2 \mathrm{fl}$.

While regarding the platelets distribution width (PDW) there was no significant difference between normal control group (7.7) and reactive thrombocytosis (7.45) but the PDW in primary thrombocytosis (8.7) was significantly higher than in both control and reactive thrombocytosis $(p<0.01)$.
The explanation of the above findings seems that MPV and the percentage of megathrombocytes in patients with myeloproliferative (primary) thrombocytosis were considerably higher than in patients with reactive thrombocytosis ${ }^{(8)}$, so the clinical importance of PDW in this regard seems to be very helpful in the differential diagnosis of thrombocytosis as PDW >9.7 was found in 9 out of 12 patients (75\%) with myeloproliferative disorders (primary) in comparison to only 9 out of 80 patients $(11 \%)$ with reactive thrombocytosis $(p<0.01)$.

A high PDW in patients with high platelets count strongly suggests primary thrombocytosis (polycythaemia vera or $\mathrm{CML}$ ).

\section{Conclusions}

Increased platelet heterogeneity through (PDW) estimation (which is increased in value) is found in most patients with myeloproliferative disorders (primary thrombocytosis).

In reactive thrombocytosis platelets heterogeneity is only sporadically seen, so a normal Platelets Distribution Width (PDW) in patients with thrombocytosis (platelets count $>$ $400 \times 10^{9} / \mathrm{L}$ ) strongly suggests reactive thrombocytosis.

\section{References}

1. Wintrobe's Clinical hematology, $11^{\text {th }} \mathrm{ed}$, volume 3, 2004:1591.

2. Robbin G, Barnard DL. Thrombocytosis and micro thrombocytosis: a clinical evaluation of 372 cases. Acta haematol 1983; 70:175-82.

3. Hoffbrand A.V., Hutton R A,Laffan M A, et al, (1999) Postgraduate Haematology, $4^{\text {th }}$ edition. Oxford, Butterworth-Heinemann Company:556.

4. Murphy S, Thrombocytosis and thrombocytosmia clin. Haematol. 1983:12:89-106.

5. Rowan RM, Fraser $\mathrm{C}$, Gray $\mathrm{JH}$, et al the coulter counter model S plus - the shape of things to come. Clin lab Hamatol 1979; 1:29-40.

6. Giles $\mathrm{C}$. The platelet count and mean platelet volume. $\mathrm{Br} \mathrm{J}$ Haematol 1981; 48:31-7. 
7. Gary SK, Amaros EL, Karparkin S. Use of megathmbocyte as an index of megakaryocyte number: $N$ Engl J Med 1971; 284:11-1.

8. J Van Der Lelie, Aeg K R Von Dem Borne: platelet volume analysis for differential diagnosis of thrombocytosis, J. CL. Path. 1986; 39:129-133.

9. Cortelazzo S, Barhni T Bassan R, et al. A normal aggregation and increased size of platelets in myeloproliferative disorders. Thromb. Hemost. 1980; 43:127-30.
10. Holme S, Simmonds $M$, Ballek R, et al comparative measurement of platelet size by coulter counter, microscopy of blood seems and high transmission studies. J Lab clin Med 1981; 97:610-22.

11. Zalla -Z, Scott $M$, and Frank $H$. Microscopic platelet size and morphology in various haematologic disorders, blood. 1978; 51 (3):479-485. 